"Mircea cel Batran" Naval Academy Scientific Bulletin, Volume XIX - 2016 - Issue 2

The journal is indexed in: PROQUEST / DOAJ / Crossref / EBSCOhost / INDEX COPERNICUS / DRJI / OAJI /

JOURNAL INDEX I I2OR / SCIENCE LIBRARY INDEX / Google Scholar / Academic Keys/ ROAD Open Access I

Academic Resources / Scientific Indexing Services / SCIPIO / JIFACTOR

\title{
ENGLISH INFLUENCE UPON ROMANIAN MARINE (ENGINEERING) TERMINOLOGY
}

\author{
Alina BALAGIU ${ }^{1}$ \\ Dana ZECHIA ${ }^{2}$ \\ ${ }^{1}$ Associate Professor PhD Electrical Engineering and Naval Electronics Department, "MirceacelBatran" Naval \\ Academy, no 1, Fulgerului street, Constanta, Romania alinabalagiu@yahoo.com \\ ${ }^{2}$ Senior Lecturer PhD, Marine Engineering and Naval Armament Department, "MirceacelBatran" Naval \\ Academy, no 1, Fulgerului street, Constanta, Romania
}

\begin{abstract}
The paper tries to identify the main changes produced upon the Romanian terminology by the English marine terms which are more and more frequently used in maritime vocabulary in general and especially in certain sub-domains like engineering. The fact that most of our graduates work on ships, in an international environment make these changes more rapid and spectacular in comparison to the influences upon the same terminology in the last century.
\end{abstract}

Keywords: marine engineering, ESP, Romanian terminology, English

\section{Introduction}

Throughout centuries a language may be influenced by other languages for various reasons. This process has sped up in the last decades, especially if we take into consideration the scientific and technical vocabulary as part of a language that is developing constantly according to the latest breakthroughs. From the etymological point of view most of the new words from the $19^{\text {th }}$ and $20^{\text {th }}$ century came from French even if the terms were initially taken from other languages like English, Portuguese, Spanish or Dutch. A second source of new terms used to be Italian language although in many cases it is difficult to establish the origins of a word between Italian and French. If in our PhD thesis (Minea, 2007) we succeeded to demonstrate that the maritime terminology was mainly influenced by French at the end of the $19^{\text {th }}$ century, and at the end of the $20^{\text {th }}$ century the English influence could be perceived for the terminology of small sport boats and merchant ships, we try to demonstrate that at the beginning of the $21^{\text {st }}$ century the English influence is extending upon the merchant maritime terminology and especially when we talk about marine engineering. The same source mentions that the greatest English influence upon the Romanian one in the $20^{\text {th }}$ century was for jobs and duties onboard merchant ships.

English influence upon the marine engineering terminology

From the middle of the last century Maritime English has been defined as an official language within the international maritime community. Most of the important maritime companies of shipping and ship construction in the 21 century are those of Sweden, Norway, England, American and states from the Far East, English being the language used on board. English is also the international commercial language that influences business terminology all over the world. We started from the allegation that English had two types of influences upon Romanian, first in a discreet way, due to the words that were borrowed by English from French, words that can be understood by the beginners because they resemble to the Romanian ones, and second influencing people working on board ships, who, speaking mainly English, use the English words even with their Romanian colleagues and teach the others unwillingly those words instead of Romanian ones.We are going to detail both ways with examples taken from electrical engineering vocabulary bibliography and questioning people working on board different ships in all duties or jobs from the Master to the cadet engineers.

A. English words used in marine engineering terminology that can be easily recognized by almost all readers of a specialty text even if they are beginners. These words could be divided in two great categories: words that are largely used in general technical or scientific texts and specific terms for (marine) engineering including words that are mostly used in the maritime terminology. Although we have gone through several specialty engineering and electrical engineering texts we can give as examples in the present paper only part of the terms that are included in each category. 


\section{"Mircea cel Batran" Naval Academy Scientific Bulletin, Volume XIX - 2016 - Issue 2 The journal is indexed in: PROQUEST / DOAJ / Crossref / EBSCOhost / INDEX COPERNICUS / DRJI / OAJI / JOURNAL INDEX / I2OR / SCIENCE LIBRARY INDEX / Google Scholar / Academic Keys/ ROAD Open Access I Academic Resources / Scientific Indexing Services / SCIPIO / JIFACTOR}

a. For the first sub-category we selected the following terms that were understood by students at engineering: abnormal, abrasion, access, accessible, accessible position, accident, accumulate, adhesive, adjusted, air, alarm, alternative, ambient, ambient air, ammonia, application, atmospheric, attention, attenuate, authorized personnel, automatic, automatically, blocked, capacity, carbon, carbon dioxide, characteristic, chemical, circulation, climatic, combustible, comfortable, company, completed, component, compression, compressor, condition, conductor, configuration, connected, connecting, connection, consumption, constructed, consumer, copper, contact, container, continuous, control, considered, correct, corrected, correction, corrosion, corrosive, cost, coupled, detect, detection, detector, deterioration, diagram, diameter, direction of rotation, disadvantage, disconnected, distance, distribution, double, duplication, dehumidified, documentation, eliminating, emission, energized, engineer, equipment, essential, evaporator, execution, exist, exit, explosive, explosive property, exposed, extreme operating condition, flammable, flammable material, flexibility, fluctuation, fluid, fluorescent, formulae, frequency, function, generated, guarded, horizontal, hotel, illumination, immediately, inaccessible, independent, indicator, indicator system, inspection, installation, installed, instruction, integrity, intermittent, international, interval, intrinsically, investigated, investigation, liquid, magnetic, magnitude, marker, mechanical transmission, membrane, minimum, nature, necessary, normal, operated, operating condition, operational, obtained, parameter, passage, passenger, penetration, percentage, periodical, perishable, permit, person, platform, portable, precaution, predetermined, preparation station, pressure, primary, process, produce, professionally, protect, protected, protection, protective, public spaces, qualification, qualified, recommendation, reconditioned, recreational space, reduced, reduction, repair, repairperson, representative, resistance, resistant, responsible, result, risk, robust, sanitary spaces, satisfaction, secondary, section, similar, simultaneously, solid, source, space, specialized, stable, standard apparatus , structure, sufficient, supplementary, support, system, technical, temperature, tested, time, total, toxic, transfer, transferred, transport, type, uninterrupted, value, valve, vapor, various, ventilated, vertical, vibration, visual indication, vital importance, zero, zone.

b. For the second category the selected specialty terms that could be clearly understood by students

DOI: 10.21279/1454-864X-16-12-051 due to their form or pronunciation are: accumulator battery, air compressors, air pumps, airconditioning, alarm systems, alarm, alternating current, alternative circuit, alternator, ammeter, anchoring, anode, armature, a-synchronous induction motor, autotransformer, azeotrope, battery system, bimetallic, bypass, cabin, cable protection, cable, certified, change-over facility, circuit, circulating pumps, circulating system, combined diesel-electric, communication circuit, communication system, commutation, commutator, condenser, conductance, contactor, converter, corrosion-resistant, cruising, diesel generators, diode, direct-coupled, distribution systems, electric propulsion, electric propulsion equipment, electrical, electrical apparatus, electrical consumer, electrical contact, electrical continuity, electrical transmission, electricity, electrolytic corrosion, electro-magnet, electronic types, electronics, embarkation station, excess current, exciter, extension cable, external source, extraction pump, filter, final sub-circuits, flexible cable, fluctuation, fluorinated hydrocarbon, Freon, frequency fluctuation, frequency meter, gas propulsion system, gas turbine, generator, harmonics, hydraulic pump, induction, inert gas, initial current, INMARSAT, inoperable, insulating material, interconnector, internal combustion machinery, internal communication equipment, isolation, lamp, lift, limit, liquefied gases, magnetic, magnetic amplifiers, malfunctions, maneuvering, marine industry, marine propulsion systems, megawatts, methyl chloride, motor, mounted, multimeter, navigation, navigational, non-conducting material, non-current, normal control system, officer, oil deposits, opposite polarity, pilot lamps, pneumatically controlled, polarity, portable electrical equipment, power, pressure tank, propulsion, propulsion machinery, propulsion motor, protective resistors, qualified personnel, radar, radio, radio installation, react, reflector, refrigerant system, regenerated energy, risk areas, rotation, rotor, scale, sensitive instrument, separator, series motor, shock, single-phase, star or delta formation, starting current, static electricity, stationary, stator, synchronizing, synchronous induction motor, synchro scope, tank pressure, tank, test lamp, thermograph, thyristor, transformer, transitory, untreated air, vertical zone, voltage, voltmeter, volt, wattmeter, yachts.

B. Another important category is formed, as we mentioned above, of words that are used onboard merchant ships in English, they do not resemble as form with the Romanian words, but they can be understood by everybody. In our opinion they are very important as they can enter the maritime 
"Mircea cel Batran" Naval Academy Scientific Bulletin, Volume XIX - 2016 - Issue 2

The journal is indexed in: PROQUEST / DOAJ / Crossref / EBSCOhost / INDEX COPERNICUS / DRJI / OAJI /

JOURNAL INDEX / I2OR / SCIENCE LIBRARY INDEX / Google Scholar / Academic Keys/ ROAD Open Access I

Academic Resources / Scientific Indexing Services / SCIPIO / JIFACTOR

terminology modifying it as French did in the last century. The words may be divided in two categories, one including general vocabulary onboard and the other containing mainly engineering terminology.

In the first category we included the words that are known and used in English by all the personnel onboard. They include parts of the ship, names of jobs and duties onboard, specific places safety equipment, deck equipment and objects that can be used by all members of the crew and some specific abbreviations that were made explicit in the parenthesis:

AS (able seaman);

accommodation;

aft;

banded store;

bay;

break time;

bridge;

Captain;

cargo;

casualty;

checklist;

chief (officer or engineer)

crane;

crewing;

damage;

deck;

drifting;

drill;

eating time;

ECDIS (Electronic Chart Display and Information

System)

EDH (efficient deck hands);

engine room;

extinguishers;

gangway;

hospital;

lifebuoy;

life-raft;

log;

lookout;

maintenance;

mast;

meeting;

navigating bridge;

network;

OS (ordinary seaman);

out of order;

portside;

quick track;

reefer;

safety;

Second (Officer)

DOI: 10.21279/1454-864X-16-12-051 shipper;

starboard;

stevedore;

tank (tanker)

terminals;

tanker;

training;

warning;

watch;

winch.

In the second category we included mechanical and electrical terms, tools and objects used by engineers onboard:

Alan key;

adjustable wrench;

automatic changeover facilities;

blackout;

boiler;

bow-thruster;

breakdown;

breaker;

bulb;

cable gland;

cold chisel;

cord;

cutter;

device;

distribution board;

emergency light;

emergency generator;

engine;

feedback operation;

flashing;

full power ahead or astern;

fuse;

glow;

high voltage;

input;

ladder diagram;

lamp;

light;

loop;

lubricating oil;

mechanical maintenance;

ohmmeter;

output;

overload;

over-speeding;

overvoltage;

output;

PLC (programmable logic controller)

pliers;

reactive power;

refrigeration;

(C) 2015. This work is licensed under the Creative Commons Attribution-Noncommercial-Share Alike 4.0 License. 
"Mircea cel Batran" Naval Academy Scientific Bulletin, Volume XIX - 2016 - Issue 2

The journal is indexed in: PROQUEST / DOAJ / Crossref / EBSCOhost / INDEX COPERNICUS / DRJI / OAJI /

JOURNAL INDEX I I2OR / SCIENCE LIBRARY INDEX / Google Scholar / Academic Keys/ ROAD Open Access I Academic Resources / Scientific Indexing Services / SCIPIO / JIFACTOR

refrigeration unit;

remote;

remote controlled;

reset;

screwdriver;

section board;

short circuit;

spark; sprinkler; standby set;

steering gear motor;

switchboard;

switch;

turning gear;

wire.

\section{CONCLUSION}

We decided to extract the common words and terms above in order to demonstrate that there is a constant influence of English language overall and English terminology in certain domains and perhaps the most "affected" is the maritime terminology. The examples of words that can be easily recognized from English specialty texts (in our case marine electrical engineering texts) are nouns, verbs, adjectives and adverbs with the same graphic form or sounding similar to the Romanian words. Some of the words like 'abnormal' entered English vocabulary from French in the $19^{\text {th }}$ century and is a word with Greek via Latin origins. Other words like 'abrasion' are of Latin origin which explains the similitude to the Romanian word, taking into consideration the fact that Romanian is a Latin language. Few words like alarm came from Italian via French, both Latin languages that explains the similitude to the Romanian word. Words like 'ammonia' entering English in the late $18^{\text {th }}$ century from modern Latin can be considered as being international words with about the same form in almost all European languages. New technical or scientific words, like 'compressor', have the same form in almost all European languages, denoting a new reality in a certain field. There are many words formed with prefixes and suffixes like 'dehumidified' that preserve their meaning and can still be understood very easy by a foreign listener. Almost all specialty terms are new and can be considered international terms. Some of them like 'voltage' are mainly used by Romanic languages mainly.

The words used in their English form are the ones that change, in time, the Romanian maritime terminology towards English. The first group of words is used both by the Deck Officers and Engineer Officers. Some words like 'accommodation', are of Latin origin, however, the original meaning acts more like a distracter for Romanian speakers in general. There are some words like 'crew' coming from French, with a change in meaning. Many words like 'aft', 'drill', 'winch' are of German or Dutch origins and are specific for ship terminology. Other words like 'bridge', 'watch' had the initial meaning coming from Old English. Words like 'log' with unknown etymology appeared in English as realities for navigation.

As for the specialized engineering terminology, this is mainly new in comparison to the rest of the vocabulary and even the general maritime terminology. Some words denote the person inventing it or the manufacturer: 'diesel engine' (named after Diesel Rudolf), 'Alan key'. There are words that have Latin origins like 'emergency', 'fuse', although they were not preserved in Romanian, at least not with the same meaning. Most terms denoting technical objects and the actions they do were formed by the existing words using suffixes, prefixes and by compounding.

\section{BIBLIOGRAPHY}

[1] Jhang, Se-Eun and Lee, Sung-Min. (2013). Visualization of Collocational Networks: Maritime English

Keywords. Language Research 49.3, 781-802.

[2] Minea, Alina, Terminologia navală maritimă in limba română. Ed. ANMB, 2007, p281.

[3] Pritchard, Boris, The English Element In The Development Of Croatian Maritime Terminology. Scientific Journal of Maritime Research . 2013, Vol. 27 Issue 1, p247-259.

[4] https://en.oxforddictionaries.com/definition 